\title{
The Legal Frameworks in the Fight against Corruption in Nigeria
}

\author{
Dr Aishatu Kyari Sandabe \\ University of Maiduguri, Borno State, Nigeria
}

\begin{abstract}
Corruption is a cancerous phenomenon that has permeated every facet of society. It has been identified as the main obstacle to the realisation of good governance, sustainable development and millennium development goals. Corruption is an impediment to political, economic and social development, hinders administrative development and performance, impairs economic efficiency, leads to brain drain, discourages foreign investments, undermines effective utilisation of natural resources and hampers transparency. While the manifestation of corruption is without limits, its roots seem to be identifiable in the immoderate inclination for material wealth and power. One of the major catalysts for widespread corruption in Nigeria is the failure in the existing legal frameworks to effectively combat corruption. The methodology adopted were doctrinal and empirical. The objectives of this study are to examine what motivates people to be corrupt, and to analyse the legal frameworks in the fight against corruption, the national, regional and international frameworks will be considered and recommend capital punishment for those guilty of grand and political corruption in order to eradicate this menace.
\end{abstract}

Keywords; Corruption, Political, Economic, Social, development, Legal frameworks, National, Regional, International

\section{INTRODUCTION}

$\mathrm{C}$ orruption is not peculiar to Nigeria alone; it is a global problem, it is a phenomenon that affects all countries, it exists in any country, at any time and under any form of government. ${ }^{1} \quad$ Corruption is a pandemic sociological phenomenon which has become a norm in Nigeria. It carries negative social Consequences, it destroys economic efficiency, social inequities and undermines the functioning of democracy. ${ }^{2}$ To fight corruption more effectively it is well established that there is need to improve understanding of its different manifestations. Corruption has impeded the ability to deal with poverty effectively and it thrives where the rewards are potentially great and the risks are potentially low. ${ }^{3}$ Preventing corruption assists to raise city revenues improve service delivery, stimulate public confidence and participation

\footnotetext{
${ }^{1}$ M Jorgensen Ferrules: What is corruption; A History of corruption studies and the great definitions debate University of California (2005) p 5

${ }^{2}$ R Fishman, M Golden: Corruption what everybody needs to know, Oxford University press (2017) p 2.

There are no sources in the current document. ${ }^{3} \mathrm{~J}$ Hanchard; Combatting corruption, Legal approaches to supporting good governance in Africa, Edward Elgar publishing Limited (2014)
}

and win elections. ${ }^{4}$ The 2019 corruption perception index (CPI) released by Transparency International ranked Nigeria 146 out of 180 countries, and it was rated 26 out of 100 points. ${ }^{5}$ The fight against corruption in Nigeria has not been won due to lack of political will. ${ }^{6}$ Corruption involves both individual states and international organisations and its costs are born by the citizens. It affects the proper running of governments, distorts the correct functioning of economic and political institutions and hampers transparency. It also affects investment. $^{7}$

\subsection{Definition}

There is no consensus on a universally acceptable definition of corruption. Transparency International, the highly rated German non-governmental organisation defined corruption as 'the misuse of entrusted power for private gain ${ }^{8}$

\section{Joseph Nye defined Corruption as:}

behaviour which deviates from the formal duties of a public role (elective or appointive) because of private-regarding (personal, close family, private clique) wealth or status gains; or violates rules against the exercise of certain types of privateregarding influence.

Joseph Nye's definition accounts for the fact that corrupt acts can be committed both by elected politicians as well as by appointed bureaucrats. his definition also accounts for the fact that the private gain can accrue either personally to the corrupt official, or to his/her family, or even to his/her extended network of family and friends.

\section{Susan Rose- Ackerman defined Corruption as:}

Both accepting a bribe in return for certifying an unsafe building and demanding a bribe as a

\footnotetext{
${ }^{4}$ R Klitgaard, R Maclean Abaroa, H Linsey Parris; Corrupt Cities: A Practical guide to cure and prevention G Press (2000)

6 Political will exists where one is likely to witness zero tolerance to corruption, the big and small fish are treated equally before the law.

${ }^{7}$ Investors will avoid environments where corruption is rampant due to increased cost of doing business and breakdown of the rule of law. Local investors seeking to invest outside their countries may find it difficult to win the confidence of potential business partners if they come from countries with high level of corruption.

${ }^{8}$ https;//www.transparency/org/cpI 2019/news/features/cpI 2019
} 
condition for approving a fully compliant structure, it includes embezzling contract funds, so a promised infrastructure project is delayed and over budget, as well as the simple theft of public funds in a way that inflates public budgets but with little noticeable effect on the level of public services. ${ }^{9}$

The world bank defined Corruption 'as the abuse of public or corporate office for private gain'. there is no definition of corruption in the United Nations Convention Against corruption (UNCAC) this is because they could not agree on a definite definition.

\subsection{Types of Corruption}

\subsubsection{Petty Corruption}

Petty corruption exists when there is abuse of entrusted power by public officials in their synergy with common citizens who are trying to access basic goods or services. It is a combination of low salaries, discretion in decision making, poor working conditions in the public service which contribute to bribe taking. This kind of corruption normally involves smaller amount of money or favour; corruption is done for economic survival rather than enriching themselves. For example, such corruptions start at the entrance of the offices whereby the gatemen are bribed in order to change the reporting time or paying the custom officials to clear goods which is banned, in many small places such as registration offices, police stations, state licensing boards, hospitals and many other private and government sectors.

\subsubsection{Grand Corruption:}

Grand corruption is defined as corruption occurring at the highest levels of government in a way that requires significant subversion of the political, legal and economic systems. Such corruption is commonly found in countries with authoritarian or dictatorial governments but also in those without adequate policing of corruption. The main motivation for grand corruption is pure greed.

\subsubsection{Political Corruption}

Political corruption is any transaction between private and public sector actors through which collective goods are illegitimately converted into private regarding payoffs. ${ }^{10}$

Political corruption takes place at the highest levels of political system and involves political decision makers, politicians, government ministers, senior civil servants etc. Corruption is when these officials who made the laws are abusing their public power for private gain. Political

\footnotetext{
${ }^{9} \mathrm{~S}$ R ACKERMAN, B J PALIFKA, CORRUPTION AND GOVERNMENT: Causes, Consequences and Reform, Cambridge University Press (2016) P 40

${ }^{10}$ A J Heidenheimer; The topography of corruption; explorations in a comparative perspective, International social science Journal. Vol 48 no3 1996
}

corruption not only leads to the misallocation of resources, but it also affects the way in which decisions are made.

Political corruption can be divided into two basic related processes.

1.3.4 Extractive political corruption; this is when political power holders are enriching themselves by abusing their hold on power to extract from public and private resources.

1.3.5 The power preserving political corruption: which is when political office holders are using the corruptly acquired means as well as resources in corrupt ways to maintain and strengthen their hold on power.

\section{CAUSES OF CORRUPTION}

The question is what are the motivating factors for corruption in Nigeria? Nigerians are firm believers in their religions and the religions teaches them to be of good behaviour and to be honest, then what went wrong? Why is corruption so pervasive in Nigeria? Without knowing the factors that make corruption thrive in this country, we cannot find solutions to this menace. The possible causes of corruption are as follows:

\subsection{Wages:}

The higher the wages paid to civil servants the less corruption. If the civil servants are paid well, what they earn will be enough to meet their family obligations I.e., to take their children to good schools, to pay rents or build houses for themselves, and have a good health care system, corruption will naturally disappear, more especially at the petty corruption level. The other problem our people face is when they retire, they are not paid their retirement benefits as at when due. Our people after retirement run into complete poverty what they receive as pensions is not commiserate to what they earn. So, their lifestyle will naturally change, this encourages corruption. So, it is a fact that low wages paid to civil servants do bread corruption.

\subsection{Weak Institutions:}

Corruption thrives when there are weak political and legal institutions in the society. Weak institutions can create an environment that reduces motivation and productivity when employees face challenges such as promotion unconnected to performance, low salaries, it is easy to be disheartened. the fight against corruption could only be effective when national institutions were strengthened to act independently. Nigeria needs strong institutions for example strong executive arms of government, strong parliaments, strong and independent judiciary as institutions that assist to ensure that governments respect the will of the people and govern by the rules of democracy and not dictatorship.

\subsection{Lack of Strict Punishment}

The punishment meted out to corrupt officials is mild. People will tend to engage in corruption when the risks are low, the 
penalties mild and the rewards are great. ${ }^{11}$ For example if capital punishment is introduced for corrupt officials it will deter others from being corrupt. Death sentence should be granted for any person who commits grand corruption and life imprisonment for petty corruption offenders.

\subsection{Demographics.}

IT has been established that men are more prone to corruption than women, but this is because the percentage of men both in the public and private sectors is far greater than women, nowadays women also prove to be as corrupt as their men counterparts in Nigeria, for example Mrs Cecelia Ibru, the former managing Director of Oceanic Bank was involved in one of the biggest female corruption in Nigeria, she was charged with money laundering of N15 Billion and other related crimes. She was only sentenced to 6 months' imprisonment; she was ordered to hand over $\$ 1.2$ billion in cash and assets ${ }^{12}$.

Dr Ndidi Okereke, former Director General of the Nigerian stock Exchange was accused of misappropriation of funds and carried out fraudulent transaction which include the purchase of N186 Million worth of wristwatches without proper account and a yacht of N39 Million. ${ }^{13}$

Stella Oduah, former Minister of Aviation purchased bullet proof cars worth N255 million.

Patricia Etteh, she was accused of spending N628 Million on renovating her official residence and that of her deputy and bought 12 official cars for the house of representative.

Iyabo Obasanjo Bello was charged by the Economic and financial crimes commission (EFCC) in 2008 for N300 Million unspent budget of the federal ministry of health. Etc.

Diezani Alison Madueke, the former minister of petroleum resources during the regime of President Goodluck Jonathan, was accused by Sanusi Lamido Sanusi, the former Governor of the Central Bank of Nigeria of not remitting US\$ 20 Billion in revenue owned to the State. Diezani was arrested in the United Kingdom for money laundering in 2015, In Nigeria the Economic and Financial Crimes Commission has accused her in many corruption cases while properties worth billions of Naira have been confiscated from her. ${ }^{14}$

\subsection{Poverty:}

a poor person is easily corruptible when he does not have the necessities of life.eg shelter, clothing food etc.

\footnotetext{
${ }^{11}$ Ibid (n4) p27

12 https://www.bbc, com/Newsworld-Africa 11506421 9/10/2010/accessed $8 / 06 / 2020$ at $1.38 \mathrm{am}$

${ }_{13} \mathrm{https}$ ://www.bing.com accessed 08/06/2020 at $2.00 \mathrm{am}$.

$14 \frac{\text { https:www/premiumtime, }}{\text { ng.com/headlines/373949-uk-govt }}$ accessed08/06/2020 at 2.43am. q
}

\subsection{Lack of Accountability:}

Corruption exists if a person has monopoly power over a good or service and has the discretion to decide whether someone gets that goods or service or how much a person receives and there is no accountability whereby others can see what that person is deciding. ${ }^{15}$

\subsection{Lack of State Funding for Elections.}

The culture of individuals or political parties funding elections encourages corruption because immediately they win the elections, they will tend to recover the moneys they had spent on the elections from public funds, if the state or the federal government funds the elections corruption will be less.

\subsection{Constitutional Lapse:}

S.308 of the 1999 constitution provides immunity against both civil and criminal prosecution for a sitting president and his vice. This also encourages corruption. Our past leaders with history of grand corruption have never been prosecuted because of the immunity clause even when they are out of office.

\section{LEGAL FRAMEWORKS FOR THE FIGHT AGAINST CORRUPTION}

The legal frameworks for eradicating corruption in Nigeria will be discussed under national, regional and international.

\subsection{The National Legal Framework}

Nigeria has enacted so many laws in order to eradicate corruption some of these are as follows:

1. The constitution of the federal republic of Nigeria

2. EFCC Establishment Act $2004^{16}$

3. Independent Corrupt Practices \& Other Related Offences Act $2000^{17}$

4. Advance Fee Fraud and Other Related Offences Act $2004^{18}$

5. Money Laundering (Prohibition) (Amendment) Act $2012^{19}$

6. Miscellaneous Offences $\mathrm{Act}^{20}$

7. Code of Conduct $\mathrm{Act}^{21}$

8. Nigerian Extractive Industries Transparency Initiative Act. ${ }^{22}$

\footnotetext{
${ }^{15}$ R. Klitgaard, R. Maclean, A.Abaroa, H.Lindsey: Corrupt Cities: A practical guide to cure and prevention. G Press institute of contemporary studies Oakland California (2000)

${ }^{16}$ Economic and financial crimes commission (establishment) Act 2004 cap EI LFN 2004

${ }^{17}$ Independent corrupt practices and other related offences Act 2000 cap C 31 LFN 2000

${ }^{18}$ Advance fee fraud and other related offences Decree No 13 of 1995 Act A6 LFN 2004

${ }^{19}$ Money Laundering (prohibition) (Amendment) Act No 11 of 2011

${ }^{20}$ Miscellaneous offences Act cap m17 LFN 2007

${ }^{21}$ Code of conduct Act cap c15 LFN 2004
} 
9. Freedom of Information Act $2011^{23}$

10. Fiscal Responsibilities Act $2010^{24}$

11. Penal Code Laws of Federation of Nigeria $2004^{25}$

12. Criminal Code Law of Federation of Nigeria $2004^{26}$

13. Banks and Other Financial Institutions (Amendment) Act $1991^{27}$

14. Failed Banks (Recovery of Debts) and Financial Malpractices in Banks (Amendment) Act 1994

This article will focus on the first three.

3.1.1 The Constitution of the Federal Republic of Nigeria 1999 as amended contains the code of conduct for public officials in schedule $\mathrm{v}$ part 1 which provides that a public officer shall not put himself in a position where his personal interest conflicts with his duties and responsibilities. ${ }^{28}$

Also, the president, vice president, governor, deputy governor, ministers, commissioners of states, and such other public officers or persons as the national assembly may by law prescribe shall not maintain or operate an account in any country outside Nigeria. $^{29}$

3.1.2 The Economic and financial crimes commission and other related offences Act.

A viable democracy will not grow let alone flourish in an environment where economic and financial crimes are endemic. Previous efforts by past administrations to deal with economic and financial crimes in Nigeria either not successful due to inadequate enabling laws and regulations or neglected for apparent lack of commitment on the part of the stakeholders to fight corruption.

The economic and financial crimes commission which was established in 2003 is the major financial crimes combatting agency in Nigeria. The commission is responsible for the:

a) Investigation of all financial crimes including advance fee fraud, money laundering, counterfeiting, illegal charge transfers, futures market fraud, fraudulent encashment of negotiable instruments, computer credit card fraud, contract scam, etc.; ${ }^{30}$

b) the co-ordination and enforcement of all economic and financial crimes laws and enforcement functions conferred on any other person or authority; ${ }^{31}$

${ }^{22}$ Nigerian extractive Industries Transparency Initiative Act cap N159 LFN 2004

${ }^{23}$ Freedom of Information Act 2011 cap A 2 LFN 2004

${ }^{24}$ Fiscal Act 2010 cap 40 LFN 2014

${ }^{25}$ Penal code laws of the federation 2004 cap P3

${ }^{26}$ Criminal code laws of the federation of Nigeria cap c28 2004

${ }^{27}$ Banks and other financial institution (Amendment) Act 1991 cap B3 LFN 2004

${ }^{28}$ Section 1 part 1 of the $5^{\text {th }}$ schedule of the 1999 constitution of the federal republic of Nigeria (as amended) p 141.

${ }^{29}$ Ibid

${ }^{30}$ Section 5 (b) Economic and financial commission (establishment) Act 2002

${ }^{31}$ Ibid c) the adoption of measures to identify, trace, freeze, confiscate or seize proceeds derived from terrorist activities, economic and financial crimes related offences or the properties the value of which corresponds to such proceeds; ${ }^{32}$

The powers of the Economic and financial crimes commission (EFCC) are to prevent, investigate, prosecute and penalise economic and financial crimes and it is charged with the responsibility of enforcing the provisions of other laws and regulations relating to economic and financial crimes.

The vision of EFCC states:

"The vision of the EFCC is to make Nigeria a safe and corruption free nation and enhance positive image of the country. An agency operating to best international standards and leading the fight against economic and financial crimes in Nigeria" 33

Also, the mission statement of EFCC reads as follows:

"The EFCC is to curb the menace of corruption that constitute the clog in the wheel of progress, protect national and foreign investments in the country, imbibe the spirit of hard work in the citizenry and discourage ill-gotten wealth, identified illegally acquired wealth and confiscate it; build an upright work force in both public and private sectors in the economy and contribute to the global war against financial crimes and terrorism financing".

"To rid Nigeria of economic and financial crimes and to effectively coordinate the domestic effort of the global fight against money laundry and terrorist financing". 34 During his Inaugural address to the nation on May 29, 1999 President Olusegun Obasanjo said:

The impact of corruption is so rampant and has earned Nigeria a very bad image at home and abroad. Besides, it has distorted and retrogressed development. Our infrastructure- NEPA, NITEL, ROADS, RAILWAY, EDUCATION, HOUSING and other social services could decay and collapse. Government officials became progressively indifferent to propriety of conduct and showed little commitment to promoting the general welfare of the people and public good. Government and all its agencies became thoroughly corrupt and reckless. Members of the public had to bribe their way through in ministries and parastatals to get attention. And one government had to bribe another government agency to obtain the release of their statutory allocation of funds. ${ }^{35}$

In April 2003, President Olusegun Obasanjo appointed Nuhu Ribadu, an assistant commissioner of police, as EFCC's first

\footnotetext{
${ }^{32} \operatorname{Ibid}(\mathrm{n} 28)$

${ }^{33}$ EFCC 2012

${ }_{35}^{34} \mathrm{Ibid}$

${ }^{35}$ Patrick E. Igbinovia, Blessing E. Igbinovia: The economic and financial crimes commission in Nigeria An appraisal (safari book Ltd Ibadan) 2014, pp $35-36$
} 
executive chairman. In 2005 the EFCC successfully prosecuted former inspector general of police Tafa Balogun. He leaded guilty to failing to declare his assets, his front companies were convicted of money laundering, and the court ordered the seizure of Balogun's assets, worth in excess of $\$ 150$ million. Even though he was only sentenced to six months in prison. In May 2007 President Obasanjo with his governors left office having served for eight years, and in July 2007 the economic and financial crimes commission (EFCC) charged some of the Governors for corruption because they could no longer enjoy the constitutional immunity clause from prosecution. In December $2007 \mathrm{Mr}$ Nuhu Ribadu was removed from office for arresting Ibori the then governor of Delta state and was replaced by Farida Waziri. Many prominent Nigerians were prosecuted by the EFCC. the EFCC's attempts to prosecute nationally prominent political figures have been characterized primarily by delay, frustration and failure.

Former Economic and Financial Crimes Commission (EFCC) Chairman Nuhu Ribadu has estimated that between independence and the end of military rule in 1999, more than US\$380 billion was lost to graft and mismanagement. ${ }^{36}$

Nigeria's political establishment, both the ruling party and leading opposition parties, welcome into their rank politicians accused of corruption. Joshua Dariye and Abdullahi Adamu, former state governors of Plateau and Nasarawa, respectively, have both been arraigned by the EFCC on corruption charges but won elections to the Senate in the April 2011 elections. Two of the legislators awaiting trial on corruption chargesIgwe Paulinus and Ndudi Elumelu - also won their elections to seats in the House of Representatives. Eight other former governors arraigned on corruption charges by the EFCC won party nominations to stand in the 2011 elections, either for governor or senator. ${ }^{37}$

The performance of the EFCC in the war against corruption has been undermined both by factors beyond the control of the EFCC as well as internal challenges within the commission.

The commission's chairman has no security of tenure and can be removed by the president at will. ${ }^{38}$ Although the EFCC is said to be an independent body to fight corruption, interference by government has undermined its effectiveness e.g., the removal of the chairman of the commission at will signify tempering with the activities of the commission.

The federal government interference with the EFCC's work has damaged the public legitimacy of anti-corruption prosecutions and deterred EFCC officials from taking up the cases the executive is likely to disapprove of, and the

\footnotetext{
${ }^{36} \mathrm{http}: / /$ news.bbc.co.uk/2/hi/africa/6069230 s t m accessed march, 232011

37 Emman Ovuakporie: 'Waziri's EFCC and the 2011 election vanguard newspaper $7^{\text {th }}$ may 2011

38 https://www.hrw.org/report 2011/08/25/corruption-trial/record-nigeriaecnomic and financial crimes commission accessed 17/06/2020
}

government should take steps to limit the power of the attorney general, to interfere in anti-corruption cases, including by amending article 174 of the constitution, which gives the attorney general power to take over or discontinue corruption or any other criminal prosecutions. And Increase the independence of the Economic and Financial Crimes Commission (EFCC). The conflicts between the Attorneys General of the federation and the heads of the Economic and financial crimes commission have threatened the progress of the war on corruption. Nuhu Ribadu was forced out of office in December 2007 because he wanted to prosecute former Delta state governor, James Ibori.

Michael Aondoakaa the then Attorney general of the federation from July 2007-february 2010, tried to undermine the independence of the EFCC and to disrupt domestic and international efforts to bring James Ibori, the former Governor of Delta state to justice. In April 2012, Ibori was convicted at Southwark crown court in London of conspiracy to defraud and money laundering sum totalling almost 50 million pounds. He was sentenced to 13 years imprisonment while the governor could have enjoyed immunity from prosecution in his home state but was vulnerable for prosecution abroad and enjoys no such immunity. ${ }^{39}$ Immunity from civil and criminal prosecution is granted to executive office holders during their tenure in office under Nigerian law. Top government officials enjoy blanket immunity from prosecution while in office. From the Nigerian standpoint, it includes immunity from civil or criminal prosecution against the holder in his personal capacity while in office. ${ }^{40}$

Mr Nuhu Ribadu said:'

' take the case of Michael Aondoakaa whose most cardinal agenda as the Attorney general of the federation seemed to be destroying EFCC by every means possible and frustrating all the cases.',

Farida Waziri was confirmed by President Umar Yar'adua as EFCC chairman in May 2008. She accused the Attorney general of the federation, Mohammad Adoke of frustrating the war on corruption. Mrs Farida said:

" the activities of the AGF office are embarrassing to the commission and have brought us in a bad light to the public perception on the fight against corruption, she said it has made the commission to lose its focus." Farida also stated that one of the challenges EFCC is facing is 'Interference and bias from people who want to decide for you who you should arrest or should not arrest. ${ }^{41}$

Mrs Waziri was removed from office by President Jonathan and replaced by Ibrahim Lamorde. He was confirmed in

\footnotetext{
${ }^{39}$ John Hatchard: Combating corruption legal approaches to supporting good governance and integrity in Africa (Edward Elgar publishing Ltd) 2014 p297.

${ }^{40}$ Section 308 of 1999 Constitution.

${ }^{41}$ Daily Trust Newspaper, Boco Edet, $27^{\text {th }}$ September 2008
} 
February 2012 by the Nigerian senate but was removed by President Buhari in 2015.

Ibrahim Magu was appointed after Ibrahim Lamorde on the $9^{\text {th }}$ of November 2015. Magu was not confirmed as the economic and financial crimes commission chairman until his suspension on the $7^{\text {th }}$ of July 2020 .

On May 29 ${ }^{\text {th }}$, 2018, the Economic and Financial Crimes Commission stated that 603 Nigerians have been convicted on corruption charges since Magu assumed duty in 2015. The EFCC confirmed that for the first time in Nigeria's history Judges and Military officials were prosecuted. ${ }^{42}$

Magu was allegedly accused of corruption, mismanagement, lack of transparency in managing recovered assets by the Commission as well as abuse of office by the AttorneyGeneral of the Federation and Minister of Justice, Abubakar Malami. ${ }^{43}$

While Magu could not be legally exonerated from all the accusations Malami seems to have exercised his constitutional power not in accordance with the dictate and spirit of the law. ${ }^{44}$

After Magu's suspension from the EFCC on the $10^{\text {th }}$ of July 2020 Muhammad Umar Abba was appointed in acting capacity.

President Muhammadu Buhari appointed the current EFCC Chairman, Mr Abdulrasheed Bawa on the $15^{\text {th }}$ of February 2021, he was confirmed by the National Assembly on the $24^{\text {th }}$ of February 2021.

\subsubsection{Independent Corrupt Practices and other Related Offences Act 2000 (Icpc)}

The Independent Corrupt Practices and other related offences commission was inaugurated on the $29^{\text {th of }}$ September 2000 by President Olusegun Obasanjo. The ICPC has three main statutory mandates, prevention, enforcement and education. The Act brings under its scope all Nigerians, in the private and public sectors and even those public officers with constitutional immunity. Like the EFCC (Economic and financial crimes commission) the ICPC is also not independent, the ICPC 2000 Act provides that every prosecution for offences under the Act shall be done with the consent of the Attorney General of the Federation. The Act guarantees the security of tenure for the chairman of the commission.

This Act in Section 6 (a-f) provides for the duties of the commission:

\footnotetext{
${ }^{42} \mathrm{https}$;//allafrica.com/201805290530htm accessed 7/3/2021.

${ }^{43}$ The Guardian, Sunday $7^{\text {th }}$ March 2021

${ }^{44}$ S 174 of the 1999 constitution gave powers to the office Attorney -General of the Federation
}

a) To receive and investigate complaints from members of the public on allegations of corrupt practices and in appropriate cases, prosecute the offenders.

b) To examine the practices, systems and procedures of public bodies and where such systems aid corruption, to direct and supervise their review.

c) To instruct, advise and assist any officer, agency, or parastatal on ways by which fraud or corruption may be eliminated or minimized by them.

d) To advise heads of public bodies of any changes in practice, systems or procedures compatible with the effective discharge of the duties of public bodies to reduce the likelihood or incidence of bribery, corruption and related offences.

e) To educate the public on and against bribery, corruption and related offences.

f) To enlist and foster public support in combating corruption.

The Corrupt Practices and Other Related Offences Act 2000 (Act 2000) brought a fresh and decisive perspective to the fight against corruption in the form of a holistic approach encompassing enforcement, prevention and educational measures. It captures in a single document, a host of corrupt offences in their old and sophisticated guises. It sets up the Independent Corrupt Practices and Other Related Offences Commission with wide-ranging powers. The Act brings under its purview all Nigerians, in the private and public sectors and even those public officers with constitutional immunity.

Despite the activities of the anti-corruption body (the ICPC), corruption within the polity continues to play the key role of causing a steady decline in the quality of governance and in the commitment to accountability thereby leading to increasing poverty and inefficiency of all public utilities. The educational sector administratively has been so affected by corrupt practices that the ICPC is now introduced in the secondary schools, higher institutions and universities in Nigeria in order to check their corrupt practices. ICPC now watches and prevents corrupt practices in our educational system - teachers, lecturers and the administrative cadre are now scared effacing prosecution by students through the assistance of ICPC. Its performance has not been too impressive because of statutory limitations regarding enforcement and the obvious non-co-operative stance adopted by public servants. It would also appear that this body is largely under-funded and, therefore, lacks operational capacities. Its powers are diverse and are mostly aimed at reducing the incidence of corrupt practices.

One effective approach ICPC used is involvement of civil servants in its anti-corruption campaign through AntiCorruption and Transparency Units (ACTU), established to operate within Ministries, Departments and Agencies (MDAs). The need to collaborate with these officials arose from the Commission's observation that those working directly in the operation of organisations should have better 
understanding and ability to identify causes and fertilising agents of corruption within their organisations.

ACTU was therefore created to serve as an extension of ICPC in the MDAs.The underlying reason for the establishment of the unit was to complement and strengthen the efforts of the Commission in the areas of monitoring, reporting and preventing corruption in the MDAs.

The unit, deriving from Section 6 (b)-(d) of the Corrupt Practices and Other Related Offences Act 2000, is empowered within MDAs to examine and review corruption-prone systems, practices and procedures, enlist the support of other public officers in fighting corruption, develop a code of ethics for staff in their MDAs same; and conduct regular anticorruption sensitisation. ${ }^{45}$ and ensure strict compliance with

Prof Itse Sagay (SAN) chairman advisory committee against corruption (PACAC) has advised the president to make the economic and financial crimes commission (EFCC) and Independent corrupt practices and other offences commission (ICPC) from the control and supervision of the ministry of justice, he said the frequent interference by the ministry in their work is seriously slowing down the anti-corruption war. $^{46}$

\subsubsection{African Union Convention Against Corruption}

Corruption remains one of the most important obstacles to the improvement of the human condition in Africa, in recognition of corruption's role in poverty and under development in Africa, The African Union convention on preventing and combating corruption was adopted by the Heads of state at the African Union summit held in Maputo on the $11^{\text {th }}$ of July 2003. The African Union convention is a major step in addressing the issue of corruption in Africa in order to bring more economic development to the continent. The convention criminalises corruption both in the private and public sector. Making it mandatory for state parties to adopt legislative, administrative and other measures to tackle corruption. ${ }^{47}$ The convention covers different types of offences including bribery, diversion of property by public officials, illicit enrichment, money laundering and concealment of property. The state parties agreed to implement the provisions of the convention in their national law and practice. This convention aims to achieve the following objectives: to

(1) promote and strengthen the development in Africa by each state party of mechanisms required to prevent, detect, punish, and eradicate corruption and related offences in the public and private sectors.

\footnotetext{
45 https:/icpc.gov.ng/2018/03/05/establishment-impacts-and challenges of anti- corruption transparency (accessed 25/06/20)

$46 \quad$ http://www.nairaland.com/561588/sagay-remove-efcc-icpc-malami accessed 27/06/20

47 Kolawale Olaniyan: The African Union Convention on Preventing and Combating Corruption: A critical appraisal https://ptds.semanticscholar.org accessed 5/7/2020
}

(2) Promote, facilitate, and regulate cooperation among the state parties to ensure the effectiveness of measures and actions to prevent, detect, punish, and eradicate corruption and related offences in Africa.

(3) coordinate and harmonise the policies and legislation between state parties for the purposes of prevention, detection, punishment and eradication of corruption on the continent.

(4) promote socio-economic development by removing obstacles to the enjoyment of economic, social and cultural rights as well as civil and political rights.

(5) establish the necessary conditions to foster transparency and accountability in the management of public affairs.

The preamble states that corruption undermines accountability and transparency in the management of public affairs and requires state parties to build partnerships between government and civil society organisations. ${ }^{48}$

The Nobel peace prize laureate Wangari Maathai said.

Let the corrupt persons return what they have corruptly obtained and let it go back to the real owners. That would make corruption a risky business. criminalise corruption so that wherever they go, the corrupt can always be apprehended, tried and handed to justice. Provide no place to hide. Let the banks and governments which keep and protect stolen wealth open their vaults. This is blood money. it leaves the children dying in hospitals which have no medicines, infrastructure which have collapsed, and water unfit for human beings to drink. $^{49}$

\subsubsection{United Nation Convention Against Corruption}

The United Nation Convention Against corruption adopted by the United Nations General Assembly on the 31st of October 2003 and entered into force on the $14^{\text {th }}$ of December 2005. It has 187 members.it is the first multilateral treaty to deal with corruption on a global basis and is also the most comprehensive international legally binding anti-corruption instrument in terms of scope of activities covered. The convention contains five areas: preventive measures, criminalisation and law enforcement, international cooperation, asset recovery and technical assistance and information exchange.

\section{(a) Preventive.}

These include preventive policies such as the establishment of anti-corruption bodies, and enhanced transparency in the financing of election campaigns and pollical parties, states must make their public services subject to promotion of efficiency, transparency and recruitment based on merit. The employed public servants must be subject to codes of conduct requirements for financial and other disclosures and

\footnotetext{
${ }^{48}$ Preamble para 10

49 Wangari Maathai, $9^{\text {th }}$ international anti-corruption conference, Durban, South Africa 1999.
} 
appropriate disciplinary measures. ${ }^{50}$ Transparency and accountability in matters of public finance must also be promoted, and specific requirements are established for the prevention of corruption, more especially in the areas of the public sector such as the judiciary and public procurement. Preventing public corruption also requires an effort from all members of society at large. The convention calls on countries to promote actively the involvement of non- governmental and community-based organisations as well as to raise public awareness of corruption. The convention enjoins each state party to establish and promote effective practices aimed at the prevention of corruption. $^{51}$

\section{Criminalisation and Law Enforcement}

State parties must criminalise bribery as well as embezzlement of public funds, other offences that state parties are required to criminalise include the obstruction of justice and the concealment, conversion or transfer of criminal proceeds. Sanctions extend to those who participate in or attempt to commit corruption offences. ${ }^{52}$

\section{(c) International Cooperation}

State parties are obliged to assist each other in cross-border criminal matters. This includes gathering and transferring evidence of corruption for use in court, to extradite offenders. States are also required to undertake measures which will support the tracing, freezing, seizure and confiscation of the proceeds of corruption. ${ }^{53}$

(d)

\section{Asset Recovery}

A fundamental principle of the convention is the right to recovery of stolen public assets. The UNCAC provisions lay a framework for states to adapt both their civil and criminal law in order to facilitate tracing, freezing, forfeiting and returning funds obtained through corrupt activities.

Effective asset- recovery provisions will support the efforts of states to redress the worst effects of corruption while sending at the same time, a message to corrupt officials that there will be no place to hide their illicit assets. ${ }^{54}$

\section{(e) Technical Assistance and Information Exchange}

Technical assistance refers generally to support aimed at helping states comply with the UNCAC's provisions. It includes provisions on training material and human resources, research and information sharing. The convention encourages the provision of training on topics such as investigative

\footnotetext{
${ }^{50} \mathrm{https}: / /$ www.unodc.org/unodc/en/corruption/convention/highlights. Accessed $13^{\text {th }} / 03 / 2021$.

${ }^{51}$ Chapter II Articles 5-14 of the United Nation Convention Against Corruption.

52 https://www.cmi. No/publication/file/3769-uncac-in-a-nutchell. Accessed $14 / 03 / 2021$.

${ }^{53}$ Chapter Iv Articles 43-49 of the United Nation Convention Against corruption.

${ }^{54}$ Chapter v Articles 51-59 United Nation Convention Against Corruption.
}

methods, planning and developing strategic anti-corruption policies. preparing requests for mutual assistance, public financial management and methods used to protect victims and witness in criminal cases.

State parties should also consider helping each other conduct evaluations and studies on the forms causes and costs of corruption in specific contexts with a view to developing better policies for combatting the problem.

The convention introduces a comprehensive set of standards, measures, are rules that all states can apply, in order to strengthen their legal and regulatory regimes to fight corruption. It calls for preventive measures and criminalisation of the most prevalent forms of corruption in both public and private sectors. And it makes member states to return assets obtained through corruption to the country from which they were stolen ${ }^{55}$

\section{RATICATION AND IMPLEMENTATION OF THE AFRICAN UNION CONVENTION AGAINST CORRUPTION AND UNITED NATION CONVENTION AGAINST CORRUPTION}

Implementation of anti-corruption conventions requires government commitment translation of convention provisions into law and practice may require allocation of important human and financial resources at operational level. Convention implementation needs experienced staff in the executive and legislative arms of government to encourage reforms. After a convention is adopted, it is then opened for signature by states, signature indicates their intent to become parties and is usually done by the executive arm of government.

To be a party to a convention and be bound by its requirements when it enters into force, a state must express its consent by ratification or accession to the convention. The procedure for doing so is laid down under national law and often requires approval by a national legislative body following consideration of the text. The approval process sometimes involves passage of national legislation. Sometimes publication in an official gazette is required as part of the process. By ratifying or acceding a state becomes a state party to the treaty. The last step in ratification process is for the government of the ratifying state to deposit an instrument of ratification with an institution or office designated in the treaty. The procedures for ratification or accession are laid down under national law and involve approval by a body and by the president. ${ }^{56}$

By all international standards and in compliance with the provision of the Vienna convention on the law of treaties, Nigeria has by signing and ratifying the convention held itself bound to perform its obligations arising from the convention.

\footnotetext{
${ }^{55}$ Kofi Annan; United Nation Secretary General.

${ }^{56} \mathrm{https}$ ://images.transparency cdn.org/images/2006. Accessed 16/03/2021.
} 
The convention obligations have the force of law in Nigeria upon coming into force in 2005. This position is stated by the provision of article 26 of the Vienna convention on the law of Treaties which provides that; ' Every treaty in force is binding upon the parties to it and must be performed by them in good faith.',

In Nigeria, the constitution provides that; "'no treaty between the federation and any other country shall have the force of law except to the extent to which any such treaty has been enacted into law by the National Assembly.",57 The issue of domesticating the convention into Nigeria's domestic legal system is the responsibility of the executive arm of government which is expected to initiate an executive bill to the National Assembly requesting that the United Nation convention against Corruption be domesticated having been signed and ratified by government of the Federal republic of Nigeria, in compliance with the provisions of Section 12 of the 1999 constitution.

\subsection{Critical Appraisal:}

\subsubsection{Policy Framework;}

The battle against corruption in Nigeria can only succeed when it is institutionalised and when there is a political will to fight corruption. The Nigerian penal and criminal codes which applies to Northern and Southern Nigeria, prohibit both the demand and receipt of bribes by public officers, both the codes did not provide for other manifestations of corruption of corruption and failed to provide enough provision for corruption. The constitution has a number of provisions which seek to eliminate corruption under the fundamental objectives and directive principle of state policy. One of the measures provided for in the constitution for monitoring corruption is the auditing process of public accounts ${ }^{58}$ the code of conduct is one of the mechanisms instituted by the Constitution for identifying corruption among public officers, the code of conduct requires a public officer to obtain from putting himself in a position where his personal interest will conflict with his official duties. The code of conduct also forbids the president, vice president, Governors, Deputy Governors, Ministers, Commissioners, and members of the National and State assemblies and such other public officers as prescribed in law by the National assembly from making or operating a foreign bank account. The independent corrupt practices act prosecutes who by laws violates existing laws on corruption. Some of the criticism of the regime relates to the provision of the Act while others relate to enforcement. The Act has no provision for questioning of the person who maintains the standard of living above what obtains with his income or punishment of additional income. The Act has no provision of encouraging whistle-blowers. The ICPC has only taken action against opponents of the President. The Attorney General during President Yaradua's regime Michael Aondoakaa undermined the independence of the anticorruption agency e.g., ICPC, EFCC and the Court of Conduct Bureau. The legal framework focuses more on public sector corruption.Nigeria has ratified both the African Union Convention on preventing and Combatting Corruption and the United Nations Convention against corruption. Both the conventions are not operative in Nigeria because of the legal provision which requires the national assembly to enact a law formally incorporating Treaties and Conventions into the domestic legal framework.

\subsubsection{Policy Implementation}

The immunity clause under section 308 of the Constitution of the Federal Republic of Nigeria precluding prosecution against some members of the public the persistent high level of corruption in the public service was due to lack of enforcement of legal regime, the legal regime to combat corrupt practices in the public service has failed to prevent corruption. The legal framework is inadequate as it contains lacuna that impair the fight against corruption. The punishment provided for in the Acts are minimal. Those found guilty of grand corruption should be sentenced to life imprisonment or death sentence.

\section{CONCLUSION}

Corruption is an insidious plaque that has wide range of dangerous effects on societies. It undermines democracy and rule of law, leads to violation of human rights, distorts markets, erodes the quality of life and allows organised crimes, terrorism and other threats to human security flourish. Lack of transparency, low wages, good governance, accountability, or institutional weaknesses, such as legislative and judicial systems lead to corruption.

Fighting corruption requires enhanced international cooperation, individual governments can make progress with domestic preventive and punitive measures, they also address the need for international cooperation and provide frameworks for technical assistance and asset recovery.

To fight corruption effectively is to change and reform policies and systems that encourage corruption not only going after corrupt individuals. Corruption tends to be reduced by the separation of powers, checks and balances, transparency, a good system of justice and clearly defined roles, responsible rules and limits. The whole culture of a society needs to change from regarding corruption as a way of life to thinking it to be unacceptable and shameful. In Nigeria to fight corruption is challenging and dangerous as indicated by Ngozi Okonjo Iweala, the former minister of Finance, her mother was kidnapped and almost murdered and they threatened to maim her for stepping on the toes of some rich and powerful

${ }^{57}$ Section 12 of the Constitution of the Federal Republic of Nigeria 1999

${ }^{58} \mathrm{~S} 125$ of 1999 Constitution of the Federal Republic of Nigeria. 
people who were involved in a corruption scandal known as the oil subsidy scam. ${ }^{59}$

To eradicate corruption completely the African Union convention against corruption and the United Nation convention must be domesticated in our national laws.

\section{RECOMMENDATION}

Wages: There should be reform in the salaries paid to civil servants, the meagre salaries paid to civil servants is not enough for their maintenances, if higher salaries are paid to them, they will be contented and will not be corrupt. INDEPENDENCE: The EFCC (the economic and financial crimes commission) and the ICPC (the independent corrupt practices commission) shall be independent of the judiciary for them to fight corruption effectively, constant Interference by the Attorney General of the federation sabotages the fight against corruption.

Education: Education is an important tool in the fight against corruption and it should be explored, how anti-corruption education can be strengthened and integrated into other disciplines including human rights education. It is important to identify the shared principles between anti-corruption and human rights, such as non- discrimination, participation, transparency and accountability.

Institute Accountability and Transparency In Government: To institute accountability and transparency in government both internal and external pressure is needed. Accountability must be generated by a combination of political will from the top and public pressure from the base.

Ratification and Domestication: The National Assembly should adopt appropriate legislation, take an active role in the ratification of relevant international instruments and incorporating their provisions in our National legislation.

Reform Public Administration and Finance Management: Reforms focussing on improving financial management and strengthening the role of auditing agencies.

Promote Transparency and Access To Information: There shall be freedom of press, transparency and access to information.

End Impunity: Effective law enforcement is essential to ensure the corrupt are punished and break the cycle of impunity or freedom from punishment. To break the culture of corruption experience indicates that big corrupt actors must be named and punished.

Special Courts and Funds: The Icpc And Efcc need special courts to try people accused of corruption, this will enable

\footnotetext{
${ }^{59}$ Ngozi O Iweala: Fighting Corruption is Dangerous, the story behind the headlines. (The MIT press Cambridge, Massachusetts London, England) 2018 pp 1-8
}

them to be proactive. The government shall provide funds to the agencies for effective prosecution of cases.

Punishment: The punishment for those guilty of grand and political corruption should be death sentence or life imprisonment so that it will serve as deterrence to others.

\section{REFERENCES}

[1] AMUNDSEN I, Political corruption in Africa: extraction and power preservation (Edward Elgar publishing co. USA 2019)

[2] ANTIGHA B A, PIUS A F, ANTIGHA B U, Corruption as a social problem and its implication on Nigerian society: A review of Anti-corruption policies (Mediterranean Journal of social sciences Vol 4(1) January 2013)

[3] BARCHAM M, HINDESS B, HARMOUR P, Corruption expanding the focus. (Australian national University press 2012)

[4] DREHER A, KOTSOGIANNIS C, MC CORRISSTON S, Corruption around the world: evidence from structural model

[5] EMUNDSON I, Political corruption in Africa, extraction and power preservation (Edward Elgar publishing Cheltenham UK 2019)

[6] HATCHARD J, Legal approaches to supporting good governance and integrity in Africa. (Edward Elgar publishing ltd, The Lypiatt's 15 Lands down Road Cheltenham UK 2014)

[7] IGBINOVIA P E, IGBINOVIA B E, The financial crimes commission an appraisal. (safari books ltd Ibadan, 2014)

[8] IWEALA, O N, fighting corruption is dangerous the story behind the headlines. (Routledge 2013)

[9] JAIN K A, Corruption: A Review (journal of economics surveys, Concordia University 2008)

[10] KLITGAARD R, Controlling Corruption (university California press ltd 1988)

[11] KLITGAARD R, ABAROA R M, LINSLEY H. Corrupt Cities: A practical guide to cure and prevention (Paris G press 2000)

[12] MBAKU M J, Corruption in Africa, causes, Consequences and Clean up (Lexington Books 2007)

[13] NMAH E P, Corruption in Nigeria: A culture or retrogressive factor (Journal of African studies Vol13 2017)

[14] NWOSUMBA C H, An Appraisal of the economic and financial crimes commission in the light of the disaster of the Nigerian anticorruption politics (journal of humanities an social sciences Vol 21 issue 2011)

[15] OLUYITAN F E, Combatting Corruption at the grassroots level in Nigeria. (Palgrave Macmillan 2017)

[16] ONIGBO A R, Analyses of legal frameworks for fighting Corruption in Nigeria: problems and Challenges. (Kuwait chapter of Arabian journal Business and Management Review Vol 5 N 3 2015)

[17] OBUAH E, Combatting Corruption in Nigeria: The Nigerian Economic and Financial crime. (vol 12 issue 12010 )

[18] RIBADU N, Obstacle to effective prosecution of Corrupt practices and Financial crimes in Nigeria. (International conference centre, Trade fair complex, Kaduna $23^{\text {rd }}-25^{\text {th }} 2004$.)

[19] ROSE-ACKERMAN Corruption and Government, causes and consequences and reform (Cambridge University 1999)

[20] RONA K, HOPE, BORNWELL, Corruption and development: lessons from country case studies (2000)

[21] SEKKAT K, Is corruption curable? (Palgrave Macmillan 2018)

[22] SHERK D R, The Cultural Dimension of Corruption: Reflections on Nigeria.

[23] SIVENSSON J, Eight Questions about corruption. (Journal of economic perspectives vol $19 \mathrm{~N} 32005$ )

[24] TAIYE D A, Gender and Corruption, Insights from Nigerian democracy (journal of International law VOL3 N 4 July 2009)

[25] The African Union Convention on preventing and combatting Corruption.

[26] The United Nations Convention Against Corruption. 